\title{
MODEL PEMBELAJARAN PENDIDIKAN KARAKTER PADA PEMBELAJARAN TEMATIK DI SD MUHAMMADIYAH 9 KOTA MALANG
}

\author{
Rina Wahyu Setyaningrum dan Husamah \\ e-mail: rinawahyus2004@yahoo.com
}

\begin{abstract}
This study aims to gain learning model of character education on thematic learning in SD Muhammadiyah Malang 9. Learning model is composed of a device and guide student learning. Acquisition of the model begins with the study of literature, observations made during this study, analysis was then prepared a draft design of the model and continued with limited testing in class 1A. Results from the trial, it is known that the prepared draft model still needs to be refined, especially in the student guide. This is because at the time of trial, the guide is still not able to guide students in learning. Sentences in the guide is still bias. Based on interviews, the students feel bothered utilizing the student guide. In addition to its unusual use guide as well as instructions for using the manual has not been so clear. But overall, this model is useful to become one of the guidelines in determining measures or policies related to improving the quality of learning in SD Muhammadiyah Malang 9, especially in the classroom where the trial.
\end{abstract}

\begin{abstract}
Abstrak: Penelitian ini bertujuan untuk mendapatkan model pembelajaran pendidikan karakter pada pembelajaran tematik di SD Muhammadiyah 9 Kota Malang. Model pembelajaran yang dimaksud terdiri dari perangkat pembelajaran dan panduan siswa. Pemerolehan model tersebut diawali dengan studi literatur, observasi pembelajaran yang dilakukan selama ini, analisis kemudian disusun draf desain model dan dilanjutkan dengan uji coba terbatas di kelas $1 \mathrm{~A}$. Hasil dari uji coba, diketahui bahwa draf model yang disusun masih perlu disempurnakan, khususnya pada panduan siswa. Hal ini karena pada saat uji coba, panduan tersebut masih belum mampu untuk memandu siswa dalam belajar. Kalimat-kalimat yang ada di dalam panduan masih bias. Berdasarkan hasil wawancara, siswa merasa repot memanfaatkan panduan siswa tersebut. Selain karena tidak biasa menggunakan panduan juga karena petunjuk penggunaan panduan belum begitu jelas. Namun secara keseluruhan, model ini berguna untuk menjadi salah satu pedoman dalam menentukan langkah atau kebijakan terkait dengan peningkatan kualitas pembelajaran di SD Muhammadiyah 9 Malang, khususnya di kelas tempat uji coba.
\end{abstract}

Kata Kunci: model pembelajaran, pendidikan karakter, pembelajaran tematik

\section{PENDAHULUAN}

Dunia pendidikan dewasa ini dihadapkan pada tuntutan yang semakin berat, terutama untuk mempersiapkan peserta didik agar mampu menghadapi berbagai dinamika perubahan yang berkembang dengan sangat cepat khususnya pergeseran aspek nilai dan moral dalam kehidupan masyarakat. Dekadensi moral dan karakter buruk yang ditunjukkan siswa merupakan contoh bagi- an yang tidak terpisahkan dalam dunia pendidikan. Selain perilaku kekerasan, isu-isu moralitas di kalangan remaja seperti penggunaan narkotika, pornografi, pornoaksi, tawuran pelajar, aborsi perkosaan, perampasan, pencurian, pembunuhan, dan tindakantindakan amoral sudah menjadi masalah sosial yang hingga saat ini belum dapat diatasi secara tuntas. Akibat yang ditimbulkan cukup serius dan tidak dapat lagi dianggap sebagai suatu persoalan sederhana (Dimyati, 
2010:85-86). Contoh perilaku tidak jujur dalam dunia pendidikan yang dilakukan siswa misalnya mencontek, menjiplak hasil karya orang lain tanpa menyertakan sumber, dan mencari-cari alasan untuk lari dari tanggung jawab atas tugas-tugas sekolah yang diberikan oleh guru (Koesoema, 2009: 183).

Banyak orang berpandangan bahwa kondisi demikian berawal dari apa yang dihasilkan oleh dunia pendidikan. Dunia pendidikan, sesungguhnya memberikan kontribusi paling besar terhadap situasi ini. Dalam konteks pendidikan formal di sekolah, salah satu penyebabnya karena pendidikan di Indonesia lebih meninikberatkan pada pengembangan intelektual semata. Aspek-aspek yang lain yang ada dalam diri siswa, yaitu aspek afektif dan kebajikan kurang mendapatkan perhatian (Koesoema, 2009:14).

Menurut Abdurrahman (2007: 74) proses pembelajaran meliputi keseluruhan unsur baik kognitif, afektif dan psikomotorik. Apabila proses pembelajaran tidak berjalan secara simultan maka akan terjadi split personality (diri yang terpisah) pada setiap siswa. Gejala split personality ini mulai tampak dalam perjalanan dunia pendidikan kita khususnya pada saat Sekolah Dasar kelas 1 (kelas rendah; usia dini). Menurut Freud dalam Erikson (1968) kegagalan penanaman kepribadian yang baik di usia dini ini akan membentuk pribadi yang bermasalah di masa dewasanya kelak. Kesuksesan membimbing anak dalam mengatasi konflik kepribadian di usia dini sangat menentukan kesuksesan anak dalam kehidupan sosial di masa dewasanya kelak. Sejalan dengan itu, menurut Hidayat (2011) kegagalan guru dalam menumbuhkan karakter anak didiknya, disebabkan seorang guru yang tak mampu memperlihatkan dan menujukkan karakter sebagai seorang yang patut didengar dan diikuti.

Menurut Hidayat (2011) jika karakter anak telah terbentuk sejak masa kecil mulai dari lingkungan sosial sampai Sekolah Dasar, maka generasi masyarakat Indonesia akan menjadi manusia-manusia yang berkarakter, yang dapat menjadi penerus bangsa demi terciptanya masyarakat yang adil, jujur, bertartanggung jawab sehingga tercipta masyarakat yang aman dan tentram sebuah suatu negara. Pendidikan yang bertujuan melahirkan insan cerdas dan berkarakter kuat itu, juga pernah dikatakan Dr. Martin Luther King, yakni; intelligence plus character... that is the goal of true education (kecerdasan yang berkarakter adalah tujuan akhir pendidikan yang sebenarnya).

Seperti yang telah diketahui, bahwa siswa kelas 1 SD (kelas awal) merupakan subyek yang perlu mendapatkan perhatian sejak dini. Masa usia dini ini merupakan masa yang pendek tetapi merupakan masa yang sangat penting bagi kehidupan seseorang. Oleh karena itu, pada masa ini seluruh potensi yang dimiliki anak perlu didorong sehingga akan berkembang secara optimal (Supandi, 1992). Usia mereka berada pada rentangan usia enam sampai dengan tujuh tahun. Pada usia ini hampir seluruh aspek perkembangan kecerdasan, misalnya IQ, EQ, dan SQ sedang bertumbuh dan berkembang sangat pesat. Tingkat perkembangan anak tersebut merupakan suatu kesatuan yang utuh (holistik) dan hanya mampu memahami hubungan antara konsep secara sederhana. Begitu pula dalam proses pembelajaran, mereka juga bergantung pada obyek-obyek yang bersifat konkret dan pengalaman yang dialaminya secara langsung atau secara empiris (Indrawati, 2009).

Berkaitan dengan hal tersebut, ada beberapa tugas perkembangan siswa sekolah (Makmun, 1995: 68), diantaranya: (a) mengembangkan konsep-konsep yang perlu bagi kehidupan sehari-hari, (b) mengembaangkan kata hati, moralitas, dan suatu skala, nilai-nilai, (c) mencapai kebebasan pribadi, (d) mengembangkan sikap-sikap terhadap kelompok-kelompok dan institusi-institusi sosial. Beberapa keterampilan akan dimili- 
ki oleh anak yang sudah mencapai tugas-tugas perkembangan pada masa kanak-kanak akhir dengan rentang usia 6-13 tahun (Soesilowindradini, 1996). Keterampilan yang dicapai diantaranya, yaitu social-help 2 skil$s$ dan play skill. Social-help skills berguna untuk membantu orang lain di rumah, di sekolah, dan di tempat bermain seperti membersihkan halaman dan merapikan meja kursi. Keterampilan ini akan menambah perasaan harga diri dan menjadikannya sebagai anak yang berguna, sehingga anak suka bekerja sama (bersifat kooperatif). Dengan keterampilan ini pula, anak telah dapat menunjukkan keakuannya tentang jenis kelamin, mulai berkompetisi dengan teman sebaya, mempunyai sahabat, mampu berbagi, dan mandiri. Sementara itu, play skill terkait dengan kemampuan motorik seperti melempar, menangkap, berlari, keseimbangan. Anak yang terampil dapat membuat penyesuaian-penyesuaian yang lebih baik di sekolah dan di masyarakat. Anak telah dapat melompat dengan kaki secara bergantian, dapat mengendarai sepeda roda dua, dapat menangkap bola dan telah berkembang koordinasi tangan dan mata untuk dapat memegang pensil maupun memegang gunting.

Sesuai dengan tahapan perkembangan anak, karakteristik cara anak belajar, konsep belajar dan pembelajaran bermakna sesebagaimana diuraikan di atas maka kegiatan pembelajaran bagi anak SD kelas awal sebaiknya dilakukan dengan Pembelajaran tematik. Pembelajaran tematik adalah pembelajaran tepadu yang menggunakan tema untuk mengaitkan beberapa mata pelajaran sehingga dapat memberikan pengalaman bermakna kepada siswa. (Sukayati, 2004). Mengingat sejatinya proses pengembangan pendidikan karakter dimulai dari kelas $1 \mathrm{SD}$ atau tahun pertama (Hasan, 2010) maka dengan demikian dalam praktek penerapannya di sekolah terintegrasi dalam pembelajaran tematik.
Hal ini juga didasarkan pada data bahwa salah satu sekolah binaan Universisitas Muhammadiyah Malang yaitu SD Muhammadiyah 9 Malang merupakan salah satu sekolah di bawah binaan Universitas Muhammadiyah Malang yang menuntut perlunya pengembangan dan pembinaan karakter siswa. Namun di sisi lain, sesuai hasil hasil wawancara dengan Wakasek SD Muhammadiyah 9 Kota Malang untuk kelas 1 pada pembelajaran tematik belum memasukkan unsur pendidikan karakter dalam pelaksanaan atau implementasinya. Ditegaskan pula bahwa pada kurikulum kelas 1 belum menerapkan pembelajaran pendidikan karakter. Selama yang ada hanya sebatas pengenalan teoritik atau wacana pendidikan karakter. Pembinaan karakter belum termasuk dalam materi yang harus diajarkan dan dikuasai serta direalisasikan oleh peserta didik dalam kehidupan sehari-hari. Ini berarti pendidikan karakter di sekolah tersebut selama ini baru menyentuh pada tingkatan pengenalan norma atau nilai-nilai dan belum pada tingkatan internalisasi dan tindakan nyata dalam kehidupan sehari-hari.

Berdasarkan dari uraian tersebut maka perlu dirumuskan desain model pembelajaran pembelajaran tematik berbasis karakter di SD Muhammadiyah 9 Kota Malang. Model pembelajaran tematik berbasis karakter tersebut akan dikembangkan secara lebih operasional sehingga mudah diimplementasikan di sekolah. Dengan demikian model pembelajaran yang diperoleh akan sangat berguna untuk menentukan langkah atau kebijakan terkait dengan pendidikan karakter baik berupa langkah perbaikan-perbaikan ataupun peningkatkan kualitas SD.

\section{METODE PENELITIAN}

\section{Metode}


Berdasarkan tujuan penelitian pada tahun pertama ini yaitu menemukan desain model pembelajaran pendidikan karakter pada pembelajaran di SD Muhammadiyah 9 Malang, maka metode penelitian yang digunakan adalah metode penelitian dan pengembangan (Research and Development) yang digabungkan dengan Metode Penelitian Tindakan.

Sedangkan tahapan penelitian yang dilakukan adalah sebagai berikut.

\section{Tahap Studi Lapang untuk Menemukan Model Faktual}

a.) Pada tahap ini melakukan studi dokumentasi dan melakukan studi lapang di sekolah untuk menemukan model faktual tentang pembelajaran pendidikan karakter pada pembelajaran tematik dengan menggunakan pendekatan deskriptif kualitatif. Sekolah yang akan menjadi tempat penelitian adalah SD Muhammadiyah 9 Kota Malang.

b.) Desain model faktual yang didapat akan diujicobakan secara terbatas di SD Muhammadiyah 9 Kota Malang, Jl. R. Tumenggung Suryo Kota Malang. Alasan pemilihan sekolah ini karena berbagai alasan yang menguatkan, sebagai berikut.

1) Sekolah Dasar (SD) Muhammadiyah 9 Malang memiliki reputasi yang baik yaitu dengan berbagai reputasi yang dimiliki.

2) SD Muhammadiyah 9 Malang merupakan SD binaan FKIP UMM.

3) Saat ini, di bawah kepemimpinan ibu Dr. Ribut Wahyu E., M.Pd, sekolah SD Muhammadiyah 9 Kota Malang berstatus sebagai sekolah yang "terakreditasi A" sekaligus sebagai salah satu SD Muhammadiyah unggulan se-jawa timur.

4) SD Muhammadiyah 9 Malang didukung dengan 25 tenaga pendidik dan 4 karyawan. Untuk menciptakan suasana pembelajaran yang unggul dan menarik, SD Muhammadiyah 9 Kota
Malang menerapkan pembelajaran tematik di kelas bawah (1-3) dan menerapkan menerapkan model pembelajaran moving class sesuai dengan mata pelajaran yang dilakukan dan bertempat di laboratorium-laboratorium yang tersedia. Seperti lab. IPA, lab. IPS, lab. Matematika, lab Bahasa dan lab. Agama. Selain itu juga, membiasakan siswa untuk sholat dhuha serta mengaji Al-Quran 15 menit pada jam pertama setiap pagi.

Kriteria yang digunakan untuk melihat keefektifan model faktual adalah peningkatan kemampuan guru dalam membuat perangkat dan peningkatan perilaku siswa yang sesuai dengan nilai-nilai: kejujuran, kedisiplinan, kesabaran, kerja sama, tanggung jawab, keadilan, kepedulian, dan ketaatan beribadah pada siswa, guru, pimpinan sekolah, dan pegawai administrasi, serta peningkatan secara signifikan pembelajaran tematik.

\section{Tahap pengembangan}

Model Faktual yang diperoleh pada tahun pertama diujicobakan/divalidasi dengan menggunakan penelitian tindakan, dengan subjek uji yang lebih luas dan lebih bervariasi karakteristiknya. Subjek uji pada tahap pilot project ini adalah SD Muhammadiyah 9 pada kelas 2 dan 3. Selanjutnya hasil ujicoba tersebut dievaluasi dan disempurnakan/direvisi sehingga mendapatkan model hipotetik.

\section{Tahap evaluasi dan desiminasi}

Tahap berikutnya, model hipotetik tersebut didiseminasi di SD Muhammadiyah 1 Malang agar model yang dihasilkan dapat digunakan. Hasil deseminasi dari model hipotetik tersebut kemudian dievaluasi untuk kemudian menghasilkan "Model Final Pembelajaran Pendidikan Karakter Terintegrasi pada Pembelajaran Tematik di SD Muhammadiyah 9 Kota Malang". 


\section{Lokasi Penelitian}

Penelitian ini dilakukan selama 2 tahun dengan lokasi penelitian adalah SD Muhammadiyah 9 Kota Malang.

\section{Instrumen penelitian}

Untuk menemukan model faktual maka dalam penelitian ini metode penelitian yang digunakan adalah metode penelitian dan pegembangan (Research and Development). Oleh karena itu, instrument yang digunakan adalah human instrument, lembar observasi dan draf wawancara.

Untuk mengevaluasi menganalisis uji coba menggunakan penelitian tindakan. karena itu, instrumen yang digunakan adalah lembar observasi aktivitas guru dan siswa.

\section{Teknik pengumpulan data}

a. Teknik Pengumpulan Data untuk Penemuan Model Faktual

Teknik pengumpulan data penelitian ini melalui observasi, wawancara in-depth, dan dokumentasi. Adapun luaran yang diharapkan dari teknik pengumpulan data tersebut seperti pada tabel di bawah ini.

\begin{tabular}{|c|c|}
\hline $\begin{array}{c}\text { Teknik } \\
\text { Pengumpulan data }\end{array}$ & Luaran/hasil \\
\hline Observasi & Catatan lapangan \\
\hline Wawancara in-dept & $\begin{array}{l}\text { Transkrip } \\
\text { wawancara }\end{array}$ \\
\hline Dokumentasi & $\begin{array}{l}\text { Perangkat } \\
\text { pembelajaran }\end{array}$ \\
\hline
\end{tabular}

b. Teknik Pengumpulan Data untuk Pengembangan Model

Teknik pengumpulan data yang digunakan adalah sebagai berikut. Data mengenai pemahaman dan sikap terhadap nilai-nilai kejujuran, keadilan, kedisiplinan, kerjasama, tanggung jawab, kepedulian, kesabaran, dan ketaatan beribadah, serta suasana sekolah dikumpulkan dengan angket, sedangkan aktualisasi nilai-nilai tersebut dalam perilaku sehari-hari digali dengan pengamatan. Data hasil studi dikumpulkan dengan tes dan pengamatan.

\section{Teknik Analisis Data}

\section{Teknik Analisis Data Untuk Penemuan} Model Faktual

Analisis dalam penelitian kualitatif dilakukan sejak sebelum memasuki lapangan, selama di lapangan, setelah di lapangan, dan berlangsung sampai ditemukan model. Data yang diperoleh kemudian dikumpulkan untuk diolah secara sistematis. Dimulai dari wawancara, observasi, mengedit, mengklasifikasi, mereduksi, selanjutnya aktivitas penyajian data serta meyimpulkan data. Teknis analisis data dalam penelitian ini menggunakan model analisis interaktif.

\section{Teknik Analisis Data untuk \\ Pengembangan Model}

Setelah model pembelajaran pendidikan karakter pada pembelajaran tematik di SD Muhammadiyah 9 Malang diperoleh, maka harus divalidasi atau diuji coba keefektifannya, yaitu dengan menguji apakah model tersebut dapat diterapkan di sesekolah dengan mengunakan penelitian tindakan.

Teknik analisis data yang digunakan meliputi: (1) ANOVA dengan taraf signififikansi 5\% untuk menghitung perbedaan skor rerata hasil tes dan angket sebelum dan sesudah eksperimen; (2) analisis dengan statistik deskriptif dan kualitatif untuk menemukan pola perubahan perilaku berdasarkan data hasil pengamatan. Apabila pada tahap ujicoba di SD Muhammadiyah 9 Malang, setelah eksperimen ditemukan perbedaan yang signifikan antara skor rerata kelompok eksperimen dan kelompok kontrol, dan ditemukan peningkatan kultur sekolah, disimpulkan bahwa Model Pendidikan Karakter Terintegrasi Pada Pembelajaran Te- 
matik di SD Muhammadiyah 9 Malang yang dikembangkan melalui penelitian ini layak diuji lagi pada tahap pilot project dengan subjek uji SD Muhammadiyah 9 Malang kelas 2 dan 3. Kemudian dilanjutkan pada tahap diseminasi di SD Muhammadiyah 1 Malang sehingga dapat dijadikan dasar untuk pengajuan usul kebijakan dalam bidang pendidikan karakter.

\section{HASIL DAN PEMBAHASAN}

Pada tahun pertama, dilakukan tahap studi lapang yang meliputi studi dokumentasi, observasi pembelajaran tematik yang saat ini dilakukan, deskripsi dan analisis temuan (model faktual), temuan draf desain model pembelajaran karakter pembelajaran tematik, penyusunan perangkat model pembelajaran karakter pada pembelajaran tematik dan uji coba terbatas. Berikut paparan dari tahapan penelitian pada tahun pertama.

1. Studi dokumentasi

Pada tahapan studi dokumentasi dilakukan studi terhadap perangkat pembelajaran yang meliputi RPP, silabus, materi pembelajaran, media pembelajaran, lembar kegiatan, lembar penilaian kognitif Bahasa Indonesia, IPS, Matematika, Lembar Penilaian Karakter dan Keterampilan Sosial yang digunakan di kelas 1 SD Muhammadiyah 9 Malang (terlampir). Hasil dari studi dokumentasi diketahui bahwa pendidikan karakter sudah tercantum secara jelas pada RPP dan silabus. Namun untuk komponen lain seperti pada materi pembelajaran, media pembelajaran, lembar kegiatan, lembar penilaian kognitif Bahasa Indonesia, IPS, Matematika, pendidikan karakter sudah secara implisit dicantumkan. Misalkan yang dicontohkan adalah gambar rumah bersih, rumah yang nyaman. Dengan memberikan contoh tersebut, maka pendidikan karakter telah dikembangkan. Hal ini secara tidak langsung merangsang karakter anak untuk berkembang. Selain itu, pada lembar penilaian karakter dan keterampilan sosial, ni- lai-nilai pendidikan karakter sudah secara eksplisit dicantumkan.

2. Observasi pembelajaran tematik yang saat ini dilakukan

Observasi terhadap pembelajaran tematik yang saat ini dilaksanakan di kelas 1 SD Muhammadiyah 9 Malang, dilakukan melalui observasi langsung terhadap pembelajarannya juga dengan observasi tak langsung. Khusus pada observasi tak langsung, dilakukan dengan memberikan angket pada Guru kelas tersebut atas nama Ibu Triana Cahyaning, S.Si dan Wakil Kepala Sekolah Bidang Kesiswaan Bapak Lutfi Kariyono, S.Pd.

Hasil observasi langsung terhadap pembelajaran tematik, diketahui bahwa dalam pelaksanaannya di kelas, pendidikan karakter belum secara maksimal dikembangkan. Meskipun guru telah berusaha mengembangkannya pada kegiatan pembelajaran, tetapi tidak semua siswa memahami yang disampaikan oleh guru. Oleh karena itu, pengembangan pendidikan karakter masih harus ditingkatkan.

Berdasarksan hasil observasi tak langsung pada guru kelas mengenai pendidikan karakter, diketahui bahwa pendidikan karakter sudah diterapkan dalam setiap KBM dan juga melalui pembiasaan sehari-hari. Pemantauan terhadap penerapan pendidikan karakter juga sudah dilaksanakan oleh pipihak sekolah yaitu melalui kegiatan supervisi oleh Kepala Sekolah. Selain itu juga melalui diskusi dan pelaporan rutin oleh tim guru kelas setiap 1 minggu sekali.

Di sisi lain, menurut Wakil Kepala Sekolah Bidang Kesiswaan Bapak Lutfi Kariyono, S.Pd pendidikan karakter sudah dikembangkan dan diimplementasikan menjadi visi sekolah. Selanjutnya, diimplementasikan pada perangkat pembelajaran, penilaian sholat, kegiatan outbond. Meskipun demikian, menurut Waka Kesiswaan pengembangannya masih perlu disempurnakan. Oleh karena itu, perlu dikembangkan pendidikan karakter dalam pembelajaran 
yang dilaksanakan di kelas 1 yaitu pembelaran tematik. Namun, secara keseluruhan pendidikan karakter pada pembelajaran tematik di SD binaan UMM ini, belum ada model baku sehingga perlu ada model pendidikan karakter pada pembelajaran tematik.

3. Deskripsi dan analisis temuan (model faktual) dan penyusunan draf model perangkat model pembelajaran karakter pada pembelajaran tematik.

Berdasarkan hasil analisis terhadap pendidikan karakter dalam pembelajaran tematik di kelas 1 SD Muhammadiyah 9 Malang, diketahui bahwa dalam rangka meningkatkannya diperlukan suatu panduan bagi guru yang tercantum pada RPP dan panduan siswa. Panduan tersebut memuat panduan aktivitas-aktivitas untuk mengembangkan pendidikan karakter dalam pembelajaran tematik. Adapun draf model pendidikan karakter pada pembelajaran tematik terlampir.

4. Uji coba terbatas

Uji coba terbatas dilakukan pada tanggal 22 Mei 2012 di kelas 1A dengan guru pendamping yaitu Ibu Triana cahyaning S.Si dan Ibu Nur Istikhoroh, S.Ag. Setelah dilakukan uji coba dilakukan wawancara pada guru pendamping dan pada siswa. Adapun hasil wawancara pada siswa, diketahui bahwa panduan siswa yang diberikan pada saat uji coba di kelas belum memberikan kebermaknaan dalam belajar. Hal ini karena, selain karena tidak biasa, panduan siswa tersebut belum memberikan petunjuk yang jelas bagi siswa. Namun, adanya panduan siswa mampu meningkatkan keaktivan belajar siswa. Sebab dalam panduan, tercantum hampir $90 \%$ gambar-gambar yang mendukung pembelajaran juga teks yang diperlukan dalam belajar. Oleh karena itu, panduan siswa ini perlu disempurnakan.

Selain itu, hasil wawancara dengan guru pendamping diketahui bahwa pada pembelajaran tematik, pendidikan karakter lebih mudah dimasukkan karena tidak ter- gantung pada saat kapan dan pelajaran yang mana yang harus dimasuki pendidikan karakter. Siswa telah terbiasa dengan etika, dan peraturan/ kontrak belajar. Sehingga, mereka telah terbiasa dengan mana yang boleh dan tidak, dan mana yang baik dan yang tidak. Ketika ada temannya yang tidak mematuhi peraturan, atau misalnya tidak mau bekerjasama, maka siswa saling mengingatkan. Jadi lebih fleksibel. Kadang kita harus memperhatikan mood siswa juga, karena kadangkala siswa akan lebih belajar ketika pada titik tertentu mereka memutuskan sendiri apa yang akan mereka kerjakan untuk mempelajari sesuatu.

Sebagai contoh, pada pembelajaran tentang bangun datar, anak-anak diminta untuk membuat desain rumah, robot, binatang, atau sesuai dengan imaginasinya masing-masing, dari bangun datar yang telah mereka pelajari. Desain dibuat di sekolah, dan diselesaikan di rumah. Tapi beberapa siswa sudah sempat menggunting kertas yang akan ditempel pada desainnya dari sekolah. Ketika pengumpulan tugas, nampak beberapa siswa mempunyai pekerjaan yang sangat bagus, tapi siswa tersebut mengaku dengan jujur bahwa pekerjaannya tersebut dikerjakan bersama orang lain di rumah. Jadi dalam hal ini siswa tidak hanya menginginkan nilai bagus, tetapi kebiasaan berlaku jujur membuat mereka mengakui apa yang mereka lakukan dengan jujur. Rupanya orang tua juga sudah ikut menanamkan kebiasaan jujur tersebut sehingga tidak meminta anaknya untuk berbohong bahwa pekerjaan tersebut dia kerjakan sendiri.

\section{KESIMPULAN DAN SARAN}

\section{Kesimpulan}

Model pendidikan karakter terintegrasi pada pembelajaran tematik di SD Muhammadiyah 9 Malang yang dikembangkan melalui penelitian ini layak diuji lagi pada tahap pilot project dengan subjek uji SD 
Muhammadiyah 9 Malang kelas 2 dan 3. Kemudian dilanjutkan pada tahap diseminasi di SD Muhammadiyah 1 Malang sehingga dapat dijadikan dasar untuk pengajuan usul kebijakan dalam bidang pendidikan karakter.

\section{Saran}

Pengembangan model pendidikan karakter pada pembelajaran tematik masih perlu disempurnakan, khususnya pada panduan siswa.

\section{DAFTAR PUSTAKA}

Anwar, Q. 2010. Nilai Agama Sebagai Acuan Membangun Karakter Bangsa. Makalah dipresentasikan dalam Sarasehan Nasional Pendidikan Karakter, Jakarta, 12 April 2010.

Dimyati. 2010. Peran Guru Sebagai Model dalam Pembelajaran Karakter dan Kebajikan Moral Melalui Pendidikan Jasmani. Cakrawala Pendidikan, Mei 2010, Th. XXIX.

Hidayat, T. 2011. Pentingnya Pendidikan Karakter di Sekolah dasar di Indonesia. Jakarta: LPI-DD.

Karsidi. 2007. Model Kurikulum Tingkat Satuan Pendidikan SD/MI. Solo: Tiga Serangkai.

Koesoema, A. D., 2007, Pendidikan Karakter: Strategi Mendidik Anak di Zaman Global, Jakarta: PT. Gramedia Widiasarana Indonesia.

Kompas. 2010. Pengguna Narkoba Mencapai 3,6 Juta Orang. Edisi Senin, 26 April 2010.

Lickona, T. 2007. Character Matters: How to Help Our Children Develop Go- od Judgement, Integrity, and Other Essential Virtues. USA: Simon \& Schuster Adult Publishing.

McBrien, J. L., \& Brandt, R. S. 1997. The language of learning: A guide to education terms. Alexandria, VA: Association for Supervision and Curriculum Development.

Pusat Kurikulum. 2007. Naskah Akademik Kajian Kebijakan Kurikulum SD. Jakarta: Depdiknas.

Sauri, S. 2010. Membangun Karakter Bangsa Melalui Pembinaan Profesionalisme Guru Berbasis Pendidikan Nilai. Makalah Sarasehan Nasional "Pengembangan Pendidikan Budaya dan Karakter Bangsa" oleh Kopertis Wilayah 3 DKI Jakarta, 12 Januari 2010.

Sirajuddin, N. 2010. Mereorientasi Pendidikan Karakter Indonesia. Harian Fajar Metro Edisi Rabu, 05 Mei 2010.

Sukayati. 2004. Pembelajaran Tematik di SD Merupakan Terapan dari Pembelajaran Terpadu. Yogyakarta: PPPG Matematika-Depdiknas.

Suyatno. 2010. Peran Pendidikan Sebagai Modal Utama Membangun Karakter Bangsa. Makalah ini disampaikan dalam Sarasehan Nasional "Pengembangan Pendidikan Budaya dan Karakter Bangsa" oleh Kopertis Wilayah 3 DKI Jakarta, 12 Januari 2010.

Williams, M. 2000. "Models of Character Education: Perspectives and Developmental Issues". Journal of Humanistic Counseling, Education and Development, 39, pp. 32-40. 